References:

1. Shneider P. L. Prospects for Korean Security// Asian Security in the 1980s. Problems and Policies for a Time of Transition. - Cambridge, 1980, p. 138-139.

2. Solomon R. H. Asian security in the 1980s: Problems and policies for a time of transition, Oelgeschlager, Gunn \& Hain, 1980, 324 p.

3. International Relations. Theory and the Asia - Pacific/ G. John, I. Kenberry, M. Mastanduno (eds.) New York: Columbia University press, 2003, p. 8.

4. Scarlapino R., Lee Chong Sik. Communism in Korea. - Berkeley: University of California press, 1972,

5. Ahu Pyong Joon. Triangle: Japan - China - USSR and Korea - Soviet policy in Asia: Expansioner Accomodation - Seoul. 1980.

6. Statement by the DPRK Foreign Ministry Representative // TSTAK, March 13th, 2002

7. Hong Min, New Cold War Opportunity, North Korea Seeking Security, Unification, Vol. 156, 2019, \# 10, p. 27.

DOI 10.31558/2617-0248.2020.5.7

УДК 327.8(73):3.071:001.4"2009/2017”

\title{
СОЦІАЛЬНО-ЕКОНОМІЧНІ ПРИЧИНИ ТА НАСЛІДКИ ПАСИВНОСТІ АДМІНІСТРАЦІЇ Б. ОБАМИ В ГЛОБАЛЬНІЙ ПОЛІТИЦІ
}

ORCID ID: https://orcid.org/0000-0003-0683-2855

Тишкун Ю. Я., к. політ. н., доцент Національного університету «Львівська політехніка»

У статті розглянуто внутрішньо-американські процеси, під впливом яких формувався і реалізувався курс глобальної політики адміністрації Б. Обами. Стверджується, що пасивна глобальна політика США у 2009-2017 рр. формувалась в умовах, несприятливих для прийняття і реалізації амбітних зовнішньополітичних рішень. По-перше, психологічної втоми американського суспільства від «нескінченних воєн» попередньої адміністрації - Дж. Буша-мол. По-друге - негативних ефектів неоліберальної економічної глобалізації для мас і промисловості Америки. По-третє - впливу на цю країну глобальної економічної кризи 2008 р. Вирішення останньої було головним завданням демократичної адміністрації у Вашингтоні, а боротьба з цією кризою зумовлювала логіку поведінки Б. Обами на внутрішній і зовнішній арені протягом багатьох років його президентства, зокрема при визначенні способів вирішення Америкою глобальних проблем довкілля, її діях в міжурядових організаціях, реагуванні на міжнародні соціальні, в т. ч. політичні кризи.

Підкреслюється, що внаслідок матеріальних і людських втрат, спричинених війнами в Іраку та Афганістані, глобальною економічною кризою, США вже до кінця 2008 р. втратили значну частину свого потенціалу «розумної» сили на глобальній арені - як воєнної могутності, так і економічного потенціалу, змушені були радикально обмежити використання воєнної складової їх «жорсткої» сили, натомість, активізувати використання такої їі компоненти, як санкційний інструментарій, роль у функціонуванні міжнародних режимів, доти доки потенціал сили Вашингтона не буде відновлено. Поряд із зменшенням ролі «жорсткої» сили Америки на глобальній арені зросло значення ії «м'якої» сили (дво- і багатосторонньої дипломатії, зовнішьої привабливості). Використання матеріальних стимулів впливу Вашингтона на інші столиці та на недержавних акторів на глобальній арені також було обмежено з огляду на потребу їх використання для подолання наслідків економічної кризи всередині Америки.

Ключові слова: гегемонія, США, Б. Обама, глобальна політика.

Tyshkun Y. Socio-economic causes and consequences of Barack Obama's administration passiveness in global policy

The article examines the intra-American processes under the influence of which the B. Obama administration's global policy course was formed and implemented. It is claimed that the passive global policy of the United States in 2009-2017 was formed in unfavorable for the adoption and implementation of ambitious foreign policy decisions conditions. Firstly, the psychological fatigue of American society from the «endless wars» of the previous administration of George W. Bush. Secondly, the negative effects of neoliberal economic globalization on the masses and industry of America. Thirdly, the impact of the global economic crisis of 2008 on the country. Solving the latter was the main task 
of the democratic administration in Washington, and the fight against this crisis determined the logic of B. Obama's domestic and foreign behavior during the many years of his presidency, including identifying ways for America to address global environmental issues, its actions in intergovernmental organizations, responding to international social, including political crises.

It is emphasized that due to the material and human losses caused by the wars in Iraq and Afghanistan, the global economic crisis in the United States by the end of 2008 lost much of its potential «smart» power in the global arena - both military power and economic potential, the country was forced radically to limit the use of the military component of their «hard» force, instead, intensify the use of such components as sanctions, the role in the functioning of international regimes, until the potential of Washington's force is restored. Along with the diminishing role of America's "hard» power in the global arena, the importance of its "soft» power (bilateral and multilateral diplomacy, external attractiveness) has increased. The use of Washington's material incentives to influence other capitals and non-state actors in the global arena has also been limited by the need to use them to overcome the effects of the economic crisis in America.

Keywords: hegemony, USA, B. Obama, global politics.

Актуальність дослідження. Глобальною політичною тенденцією XXI ст. стає протистояння великих держав, яке посилюють боротьба за контроль за рідкісними і невідновлюваними природними ресурсами в умовах планетарної екологічної кризи, конкуренція за розміщення виробничих потужностей і отримання якісної робочої сили, змагання за право розробляти і контролювати технологію штучного інтелекту тощо. Позиції Сполучених Штатів як учасника цієї конкуренції виглядають неоднозначно. Робота їх промисловості та масштаби споживання ресурсів і готової продукції їх населенням сприяють поглибленню кризи довкілля, що загрожує перетворенням згаданої боротьби держав у катастрофічну для всіх гру з нульовою сумою за недостатні для людства ресурси. Масштабні проблеми із забезпеченням американців медикаментами i засобами захисту під час пандемії COVID-19 засвідчують обмежені успіхи Вашингтона в конкуренції за виробничі потужності, принаймні, у високотехнологічних медичній та фармацевтичній галузях. США вже демонструють межі своїх можливостей у змаганні із КНР за кваліфіковані кадри. Єдина сфера, у якій зараз Америка зберігає лідерство на фоні Китаю $\mathrm{i}$, особливо, решти держав, - це розробки і застосування штучного інтелекту. Хоча результати цього аналога космічної гонки у XXI ст. неможливо передбачити. Зазначені проблеми офіційний Вашингтон тривалий час намагається компенсувати першістю у воєнній сфері і об'ємами національного ВВП. Оскільки тривале збереження глобальної першості США за цими показниками не гарантоване, то Америка повинна знайти в собі мотивацію і можливості до успішного розвитку в інших сферах, які допоможуть їй і зберегти згадані вище переваги, і ширше - дозволять перемогти у змаганні великих держав, або принаймні не програти, чи то в тривалій майбутній «новій» «Холодній війні», чи то короткій - «гарячій».

Всі ці чинники зумовлюють для США необхідність на певний час зосередитись на вирішенні національних проблем, що виникли за період «Холодної війни» з СРСР і глобальної залученості 1990-2000рр., i для цього сконцентрувати значні ресурси, забравши їх із сфери зовнішньої політики. Це зумовлює для Вашинтона необхідність тимчасово припинити участь у вирішенні глобальних проблем, часом навіть ціною репутаційних втрат і поступок на користь конкуруючих великих держав, для того, щоб з часом повернутись до активної глобальної політики на основі відновленого потенціалу власної сили (могутності).

На нашу думку, такий глобальний відступ США задля вирішення внутрішніх соціальних, зокрема економічних, проблем ми бачимо протягом каденцій останніх двох президентів, починаючи з Б. Обами. В цьому плані офіційна відмова Америки часів Д. Трампа від глобального лідерства виглядає лише продовженням зовнішньої пасивності Б. Обами. Своєю чергою результат найближчих виборів президента США, з цієї т. з., буде свідченням того, яка з двох останніх адміністрацій - демократична чи республіканська краще вирішувала проблеми глибинної Америки і забезпечувала відновлення іiї потуги, а також краще перекладала вирішення проблем планети на решту людства.

Огляд літератури. Проблематика діяльності Б. Обами і його адміністрації, як і його зовнішня та економічна політики широко досліджені в американській, російській і українській науці та публіцистиці. Б. Обама відрізняється від своїх попередників тим, що став об’єктом уваги публіцистів і науковців ще в період його боротьби за посаду президента, а не лише в час перебування на ній. Зокрема, для науковців стали актуальними дослідження не вирішених досі в Америці проблем - реформи медицини, видобутку сланцевого газу, використання інтернет-технологій як засобу політичного впливу і маніпулювання; наслідки здійснюваних ним курсів та пов'язані з ними уявлення та неологізми $[1$, с. 12]. Зокрема 3-поміж американських академічних кіл економічний контекст діяльності адміністрації Б. Обами у глобальній політиці згадували такі дослідники, як: Р. Хаас [24], К. Фейр, Р. Лесснер [25]. У свою чергу серед європейських дослідників, які досліджували зазначену проблему, можемо згадати А. Менделя-Никоровіча, Дж. Шапіро, С. Темпель, М. Заборовського, Д. Корскі, Л. Бассетс, Д. Леві, У. Гуеро, В. Чернева, Р. Гован, А. Вілкенса. Серед російських це Є. Давиборець [4], Д. Свстаф'єв [6], Л. Зубченко [7], В. Камєнєва [5], Е. Кириченко [8], 
М. Костюніна [11], С. Надточєва [1], Р. Садуов [16; 17], О. Татарінова [19], А. Уманская [21], О. Фролова [23], серед українських науковців вирізняються Н. Городня [3], М. Непийвода [2], В. Новицький [13], І. Погорська [14], Л. Смола [18], М. Фесенко [22], з білоруських -А. Косов [10], серед центрально-азійських Р. Махмудов [12].

Мета роботи - розглянути внутрішньо-американські мотиви акценту адміністрації Б. Обами на внутрішній, а не глобальній політиці США, що проявились у активних внутрішніх соціально-економічних реформах на шкоду реакції Америки на глобальні виклики, зокрема безпекові. Завданнями цієї роботи є: поперше, з'ясувати вплив внутрішньої, зокрема, соціально-економічної, ситуації в Америці на контекст формування американських глобальної стратегії і політики у 2009-2017 рр.; по-друге, вплив економічних чинників на реалізацію планетарної політики адміністрації Б. Обами, який відображається і на діях команди чинного президента США - Д. Трампа.

Виклад основного матеріалу. Традиційно глобальну політику як боротьбу за владу над планетою, участь у вирішенні глобальних проблем і формуванні міжнародної спільноти зводять до зовнішньополітичної діяльності великих держав і наддержав, які в такий спосіб забезпечують власні фундаментальні безпекові інтереси, змушуючи інших акторів діяти у власних інтересах. Незалежно від того, який курс зовнішньої політики вони реалізують: агресивний (вирішення своїх проблем за рахунок інших), активний (спроба підтримання балансу між зовнішньою і внутрішньою політикою) чи консервативний (збереження власних позицій і створених раніше сфер впливу), в будь якому випадку внаслідок глобалізації та міжнародної інтеграції наслідки їх дій будуть відчуватись в різних точках планети і матимуть найрізноманітніший вплив на інших державних і недержавних акторів усіх континентів.

Зараз завдяки можливостям, створеним глобалізацією акторами глобальної політики можуть бути не лише великі держави і наддержави, але й малі та середні держави і навіть недержавні актори. Втім, умовою активної участі у глобальній політиці (глобальної суб’єктності) будь-якої держави $є$ накопичення нею потенціалу міжнародного впливу або ж «акумуляція сили» (в термінології Р. Штрауса-Гуппе). Цей потенціал може сягнути рівня «відчутної» (за Р. Клайном) або ж «оптимальної» і навіть - «максимальної» (за Р. Штраусом-Гуппе) сили [9, с. 534-535]. Це передбачає накопичення «розумної» сили - «жорсткої» (фізичної або воєнної) і «м'якої» (впливу) - економічної, соціальної, психологічної; «об'єктивної» (кількісної, вимірюваної - воєнної, економічної i демографічної) i «суб'єктивної» (стратегії і волі- виключно інтуїтивно оцінюваних). Однак, якщо про стратегічні наміри еліти певної держави і ії готовність реалізовувати власну глобальну стратегію зовнішнім спостерігачам можна лише здогадуватись, то могутність - військову (чисельність і об'єми матеріального забезпечення арміï) і економічну (природні ресурси і можливість їх експлуатувати власною промисловістю), демографічну (чисельність, освіченість, професійність і здоров'я населення) можна прорахувати. Причому підгрунтям воєнної сили глобальної потуги, ії «великодержавності» $є$ саме «критична маса» сили держави - іiі економічний (ресурсний і промисловий) та демографічний потенціал.

Зв'язок між «суб'єктивними» і «об'єктивними» показниками сили держави проявляється в «поворотні» моменти розвитку глобального політичного процесу, коли його вектор невизначений, а дії, і бездіяльність національних еліт однаково спричиняють незворотні наслідки для існування, безпеки і добробуту певної держави, iï оточення. В такі моменти підтримка ідей еліт масами і їх спільна воля до дій, підкріплені матеріальною силою впливають не лише на долю окремої країни, але й на вектори глобального розвитку. Натомість стратегічні ідеї еліт, не підкріплені підтримкою мас та «об'єктивними» показниками сили залишаються інтелектуальними спекуляціями, як, наприклад, геополітичні ідеї К. Хаусхофера чи О. Дугіна.

3 огляду на це ми можемо припустити, що передумовою низької активності США у глобальній політиці впродовж обох каденцій Б. Обами була саме втрата якогось із їх параметрів (виявів або проявів) сили: чи то суб'єктивних (зникнення глобальних стратегічних цілей і бажання та готовності їх переслідувати), чи то об'єктивних (воєнних, економічних чи демографічних). В першому випадку - ми говоримо саме про суб'єктивний чинник - певні дії чи бездіяльність Б. Обами і його оточення, в яких їх, наприклад, звинувачує Республіканська партія США і іiі лідер Д. Трамп [20; 27], тоді як в другому - про реальні проблеми американського суспільства, на основі праці якого і має формуватися матеріальна складова сили «самотньої супердержави» (напр., за Р. Хаасом [Див.: 24]).

3 огляду на це ми можемо розглянути як внутрішньоамериканський соціальний, зокрема економічний $\mathrm{i}$ психологічний контекст, в якому обирався на посаду кандидат у президенти Сполучених Штатів Б. Обама, наявність якого визначала пропозиції цього кандидата стосовно глобальної політики і стратегії Вашингтона у випадку його обрання, так і контекст його діяльності на посаді як керівника найпотужнішої держави планети.

Так, на момент перемоги на виборах президента США у 2008 р. Б. Обами діяльність його попередника на посаді - республіканця Дж. Буша-мол. підтримувала меншість американців (лише $32 \%$ позитивних відгуків у квітні 2008 р.) [19, с. 126]. Ці соціологічні дані можна вважати (опосередковано) негативною оцінкою агресивного курсу глобальної політики США, який проводили республіканці-неоконсерватори у 2001-2008 pр. В контексті нашої роботи - ці дані і $є$ свідченням неготовності американських мас підтримувати попередню (республіканську) глобальну стратегію, ознакою втрати Америкою одного із їі показників сили (суб’єктивного) - політичної волі мас виборців цієї країни. Без неї (волі мас підтримувати агресивну зовнішню 
політику) продовження демократичною адміністрацією Б. Обами агресивного курсу глобальної політики республіканської команди Дж. Буша-мол. (активне протистояння Росії, зміна режимів воєнним шляхом і підтримка спонтанних демократизацій за кордоном тощо) було в принципі неможливим. Навпаки, в умовах затяжних і непопулярних в масах воєн в Іраку та Афганістані Б. Обама отримав від своїх виборців мандат саме на реалізацію менш активного курсу глобальної політики. Хоча, цей народний мандат не визначав, наскільки пасивними мають бути США у глобальній політиці надалі. Тому з одного боку демократична команда успадкувала від республіканської «нескінченні війни» 3 «аль-Каєдою» в Іраку та Афганістані, які продовжувала на початках під керівництвом чинного на той час республіканського міністра оборони Р. Гейтса, відповідального за продовження глобальної війни проти «Аль-Каїди», розпочатої 11.09.2001р.; боротьбу із поширенням зброї масового знищення, в рамках яких продовжувала тиск на Іран та Пн. Корею, доповнивши їх ініціативою Б. Обами стосовно глобального «ядерного нуля», та просування питання прав людини в глобальній політиці. Однак, з іншого боку, демократи неактивно, більше риторично підтримали демократизацію Бл. Сходу, спричинену «арабською весною», на відміну від попередників - республіканцівнеоконсерваторів, які підтримали «кольорові революції» в пострадянських і посткомуністичних країнах. Також нова адміністрація пасивно зреагувала на нову терористичну загрозу, породжену ІДІЛ, на відміну від відгуку іiі попередників на виклик «аль-Каєди», кинутий Америці 11.09.2001 p. і на чергову агресію РФ у пострадянському просторі, на противагу до реакції адміністрації Дж. Буша-мол. на напад Москви на Тбілісі 08.08.2008 р. Щобільше, в тих випадках, коли справа йшла про вирішення глобальних проблем демократична адміністрація намагалась розділити свої витрати і зусилля з іншими державами і міжнародними організаціями, як у випадку боротьби з ІДІЛ, режимами М. Каддафі та Б. Асада, російської агресії, кліматичної кризи, а при вирішенні регіональних проблем - перекласти їх на плечі інших, як це мало місце із постконфліктним врегулюванням в Лівії після загибелі М. Каддафі чи спробами добитись стійкого перемир'я між Росією та Україною на Донбасі.

Тому звинувачення демократичної адміністрації Б. Обами його наступником Д. Трампом [20] i активним прихильником останнього Р. Джуліані [27], в меншій глобальній активності впродовж його каденції, зокрема у допущенні агресії РФ проти України, є почасти справедливим. Однак, не тому, що це випливало із бажань самого президента-демократа і ключових персон його адміністрації, а тому, що він змушений був слідувати запитам виборців як опори своєї легітимності в умовах сталого поліархічного режиму.

Відповідно, нам слід визначити чинники, які реально зумовили певну міру пасивності Б. Обами в глобальній політиці у відповідь на суспільні запити американців. Такими факторами стали як підсумки президентства Дж. Буша-мол., так і глобальна економічна криза 2008 р. які, на нашу думку, істотно зашкодили «критичній складовій» (об’єктивної) «жорсткої» сили США, а саме таким іiі проявам як економічний (промисловий) i демографічний потенціал, знизивши іiі не лише нижче «максимального», але навіть «оптимального» рівня. Це і змусило нового лідера США, в першу чергу, займатись вирішенням внутрішніх проблем власної країни, як передумовою накопичення іiї силового потенціалу, відновленням його «оптимального» рівня. Це і стало передумовою реалізації як активного, так і агресивного курсу глобальної політики Вашингтона згодом.

Зокрема підсумки президентства Дж. Буша-мол. були такими: зменшення «критичної маси» могутності Америки - послаблення іiі «жорсткої» сили (фізичної) - воєнної, економічної та їх індустріальної бази, погіршення якісних характеристик населення Америки; зміна стратегічних намірів еліти США через втрату нею волі до використання ресурсів країни для досягнення ії глобальних цілей і вирішення проблем людства; небажання мас Америки підтримувати глобальні владні рішення Вашингтона, зміна (погіршення) уявлень американців про їх можливості.

Першим зі свідчень втрати США свого глобального впливу («сили») за часів президентства Дж. Буша-мол. стала нездатність Вашингтона примусити та/або спонукати інших акторів планетарної політики діяти в інтересах Америки. Це проявилось, зокрема, у «відкаті» останньої хвилі демократизації посткомуністичних країн та провальному втіленні ідеї примусової «зміни [політичних] режимів» на Бл. I Сер. Сході; нездатності неоконсервативної адміністрації використати інструментарій превентивної дипломатії з метою недопущення російсько-грузинської війни і поразки у ній останньої, а також зупинити ерозію індустріальної бази і людського капіталу США внаслідок неоліберальної економічної глобалізації. Все це ілюструє раніше сформульовану Дж. Розенау тезу про обмеження можливостей впливу супердержав на інші держави та недержавних акторів в сучасних умовах [15].

По-друге, витрати на глобальну експансію республіканської адміністрації, у поєднанні із планетарною фінансовою кризою, що почалась, але не «досягла дна» «під завісу» президентства Дж. Буша-мол. (і визначала фон та ключовий вектор зусиль його спадкоємця), суттєво послабили таку «критичну» складову об'єктивної сили Вашингтона, як його економічний потенціал. Зокрема, підсумком діяльності 43-го президента США (Дж. Буша-мол.) стали негативні показники макро- та мікроекономіки країни. Так, на першому (макро-) рівні відзначалися: найвищий з часів ІІ світової війни об’єм дефіциту федерального бюджету - 1,42 трлн дол. (9,9\% ВВП) у 2009 р. (фінансовому) [12, с. 69]. Зокрема, воєнні видатки США, які менш ніж за декаду (20012010 рр.) сукупно сягнули майже 1 трлн дол. [12, с. 69] - 2/3 річного бюджетного дефіциту федерації. Дефіцит бюджету, викликаний федеральним фінансуванням медичних потреб громадян лише в 2009 р. поглинав 
16,3\% ВВП при тому, що державні медичні страховки не охоплювали всіх американців, а якість медичних послуг була недостатньою [6, с. 38-39]. Ще у 2007 р. торгівельний дефіцит («поточного рахунку») Америки склав 5,1\% ВВП [19, с. 126-127], а зовнішній борг Вашингтона сягнув 17,9\% ВВП. Це супроводжувалось, водночас, зростанням до історичного «максимуму» ціни на імпортну нафту і залежності США від неї та від імпорту енергоносіїв загалом [6, с. 37-38].

На мікрорівні (домогосподарств) економічними підсумками президентства Дж. Буша-мол. були такі негативні сценарії: - збільшення: 1) числа бідних на 5 млн. ос. - до 37,3 млн. (з доходом менше 5 тис дол. на рік); 2) кількості безробітних до рівня 6,1\% працездатного населення у серпні 2008 р.; а американців без медичної страховки - до 15,3\% у 2007 р.; 3) зростання вартості навчання у вишах на 23\% у 2007-2008 н. р.; 4) зниження темпу росту зарплат до $1,8 \%$ у 2008 р. [19, с. 126-127]. В цих умовах скоротився середній клас США - основа соціально-економічного розвитку країни і гарант її політичної стабільності і зросла кількість їх незаможних громадян, які потребували уваги держави, підвищився рівень доходів найбагатших: $5 \%$ найбагатших американців стали отримувати всі 22\% доходів населення, а 20\% багатих - 51,2\%, тоді як решта $75 \%$ американців - лише $26,8 \%$ сумарних доходів населення країни [6, с. 41$]$.

За декілька місяців до президентських виборів 2008 р. контекст завершення діяльності республіканської адміністрації сформувала найглибша з часів II світової війни глобальна (циклічна) економічна криза [6, с. 34]. Для фінансового сектору Америки вона була найпотужнішою з часів Дж. Кеннеді і поставила під загрозу банкрутства дві найбільші страхові ТНК планети («AIG», «СityGroup») та 9 великих банків країни. Їх врятували від зникнення лише наймасштабніші в історії США державні інвестиції (де-факто їх націоналізація федеральним урядом через пакети акцій). Вона почалась на американському ринку іпотечного кредитування, перекинулась 3 нього на банківський сектор і - згодом - охопила весь фінансовий ринок країни, i зрештою - планети та погіршила описані вище негативні економічні показники США. Криза швидко перекинулась в реальний сектор економіки і набула рис структурної, підірвавши старі, неефективні уклади і способи виробництва, форми господарювання Америки на користь нової глобальної інформаційної економіки $[13$, с. 3]. Це призвело до погіршення якості життя громадян США, зменшення «критичної маси» сили Америки (стану фізичного і психологічного здоров’я ії населення). Центробанк США - Федеральна резервна система в цих умовах (системної економічної кризи), яка «не досягла дна», втратив монетарний контроль над американською економікою. Як наслідок, і американське суспільство, і ринкові гравці негативно оцінили антикризовий план «стабілізації фінансової системи» адміністрації Дж. Буша-мол. - резервування 350 млрд. дол. для попередження проблем з фінансовими активами [12, с. 69], як неефективний, нечіткий i запізнілий [8, с. 35], не зважаючи на те, що він таки попередив паніку. Це викликало невдоволення тодішніх американців заходами республіканської адміністрації з подолання небаченої в США початку XXI ст. економічної кризи [8, с. 35-36; 13, с. 3], вразило їх відчуття «гордості» за власну країну, похитнуло віру в майбутнє Америки, іiі глобальне лідерство та можливості [4, с. 248]. Через це (а також через невдалі боротьбу з тероризмом і «просування» демократії) знизились і готовність американських мас підтримувати досягнення глобальних цілей держави, висунутих республіканською частиною ії національної еліти і їх готовність витрачати на це ресурси. Та й самому істеблішменту держави стало не до агресивної глобальної політики в умовах поглиблення системної кризи всередині країни.

У таких умовах - економічних та соціально-психологічних ключові посади у Вашингтоні обійняла команда Б. Обами. Вона змушена була виходити з того, що Сполучені Штати втратили частину своїх сили i авторитету на міжнародній арені. Це не дозволяло їм реалізовувати ані агресивний курс в глобальній політиці, орієнтований на вирішення своїх проблем за рахунок інших держав та недержавних акторів, ані активний, орієнтований на пошуки балансу між внутрішньою і зовнішньою політикою, оскільки «стан економіки вимагає дій, рішучих і швидких [при вирішенні проблем]», заявив Б. Обама під час інавгурації. Через це у демократичної адміністрації не залишилось альтернатив реалізації консервативного курсу у глобальній політиці, - збереженню досягнутих раніше позицій на Землі задля відновлення потенціалу «відчутної» сили, втраченого за президентства Б. Клінтона та Дж. Буша-мол.

Задля імплементації нової зовнішньополітичної цілі- накопичення значного потенціалу «розумної» сили - адміністрація Б. Обами зосередилась на вирішенні проблем всередині країни, плануючи і реалізуючи систему взаємопов'язаних заходів з відновлення складових «відчутної» сили держави - ііі «критичної складової». По-перше, вони акцентували на ії соціальних складових (покращення стану громадського здоров'я і психологічних характеристик, підвищення рівня освіти і соціальної захищеності) населення США, ураженого глобальною економічною кризою, подолання негативних наслідків, спричинених диспропорціями вікової структури американського суспільства. По-друге, планувалось розширення ресурсної (енергетичної) бази економіки країни, в т. ч. їі індустрії, їх відновлення. По-третє, використовувалась дипломатія для відкриття глобальних ринків товарів і послуг для американської індустрії (короткостроковий зовнішньо-політичний пріоритет), як основи для зростання могутності Сполучених Штатів, оскільки економічний потенціал федерації трактувався як джерело іiі впливу за кордоном, згідно Стратегії національної безпеки 2015 р. [26, p. 2, 5, 6, 7]. I, врешті-решт, планувалось узгодження позицій населення і еліти країни щодо поточного і майбутнього курсу міжнародної політики США, формування їх спільної волі, необхідної для прийняття і реалізації важливих для Вашингтона рішень на глобальній арені. 
Ці заходи були розроблені та імплементовані згідно із американським досвідом боротьби з руйнівними фінансовими кризами (часів Дж. Кеннеді, Ф. Рузвельта, Е. Джексона, Т. Джефферсона), i, за зразком дирижистського, кейнсіанського «Нового курсу» 1930 pp. - політики активного втручання держави в економічне життя.

Так, з метою вирішення стратегічного завдання - покращення стану здоров'я населення США як основної складової їх «сили» (демографічного/суспільного потенціалу) на міжнародній арені федеральна влада виділила 207 млрд. дол. на підвищення якості медичних послуг, їх ефективності [6, c. 36, 38-39; 8, с. 34]. Ця масштабна реформа (принципів побудови федеральної системи медичного страхування, відомої як «Medicaid») дозволила включити всіх американців у базу даних національної медичної інформаційної системи i, водночас, знизити фінансове навантаження на федеральний бюджет Сполучених Штатів через передачу ними медичних витрат на громадян страховим компаніям - 0,1 трлн. дол. упродовж перших 10 р. впровадження програми і 1 трлн. дол. - в наступні 10 р. Це оздоровлення федеральних фінансів завдяки припиненню зростання їх витрат на медицину, які десятиліттями породжували дефіцит бюджету, з 2016 р. доповнились національною програмою пошуку ліків від раку, як для покращення стану здоров’я американців, так і для надання відповідних послуг на глобальному медичному ринку [6, с. 39, 40; 11, с. 129].

Покращення соціальних характеристик населення США, зниження рівня їх фрустрації і підвищення рівня їх очікувань забезпечувалось комплексом таких заходів, як: 1) рефінансування 45 млн. домовласників із якісною кредитною історією i зниженням іпотечних платежів у «Fannie Mae» i «Freddie Mac» ще для 3-4 млн. власників житла, забезпеченням опіки над ними з боку Federal Housing Finance Agency [8, c. 34,35], 2) захист банківських і страхових заощаджень американців через тимчасове підвищення федеральних гарантій щодо депозитів в банках і кредитних спілках із 100 до 250 тис. дол. (3 2008 р. по 31.11.2009 р. [8, с. 35-36]); 3) надання американським урядом банкам коштів з метою кредитування населення (до 2 трлн дол. [13, с. 4]); 4) створенням робочих місць (в об’ємі 1-3,6 млн.), з яких до 160 тис. були створені виключно корпораціями «Крайслер» і «Форд»; 5) спрощення для 95\% населення при купівлі вітчизняних авто; 6) роздача талонів на харчування для найбідніших американців (на 20 млрд. дол.); 7) надання всім бажаючим (7 млн. ос.) можливості отримати вищу освіту на рівні коледжу через податкові кредити у розмірі 2,5 тис. дол. на особу на зазначену ціль.

Особливу увагу було сфокусовано на вирішенні масштабної проблеми (і соціальної, і демографічної), обумовленої віковими особливостями населення сучасних США: структурної кризи системи соціального забезпечення, зумовленої масовим виходом на пенсію післявоєнного покоління («бейбі-бумерів», народжених в 1950-1960 рр.), яке перевантажило систему медичного соціального забезпечення Штатів [6, с. 38-39].

Наслідками восьмирічної діяльності адміністрації Б. Обами стали: збалансування державних витрат на декаду вперед, збереження довіри домогосподарств до національної економіки, підвищення доходів та рівня життя і освіти американців,стимулювання їх споживання [6, с. 34, 37], зниження темпів соціальної диференціації США. За рахунок згаданих вище заходів було забезпечено відновлення демографічної складової «критичної сили» держави (освіти, професіоналізму і здоров’я американців).

Відновлення економічного потенціалу глобальної могутності США, зокрема, їх індустріальної бази вимагало зростання споживання останніми природних ресурсів, головно, енергетичних. Ідеться про зростання рівня зовнішньої залежності Америки і зниження рівня її енергетичної безпеки. Задля вирішення цієї дилеми адміністрація Б. Обами, користуючись тим, що глобальна економічна криза зруйнувала старі економічні уклади і галузі, сфокусувалась на використанні досягнень альтернативної енергетики і «сланцевої революції» в нафтогазовій сфері [6, с. 38]. Так, реалізуючи «вагому» енергетичну політику Б. Обама акцентував увагу на розвитку альтернативної енергетики, цільово виділивши на ії розвиток 150 млрд. дол. і ще частину коштів від продажу квот на викиди шкідливих газів [22, с. 9]. Апробація цих технологій дозволила зацікавити інвесторів [6, с. 38] і забезпечила успіх стратегічної реформи, яка зменшила залежність США від імпорту енергоносіїв. У зв'язку з цим, адміністрація Б. Обами зайнялась відновленням економічної компоненти могутності держави, особливо їі індустрії та інфраструктури як складових «критичної маси» сили держави на міжнародній арені. Основною для цих дій стали оцінки, згідно з якими ринок США, станом на 2009 р.,генерував до 40\% попиту на товари і послуги, 21\% ВВП [12, с. 70] і 20\% виробництва планети [3, с. 18], а також те, що американські робітники - найпродуктивніші на Землі [5, с. 83]. Демократична адміністрація зосередилась на створенні основи для відновлення «welfare state» (держави загального добробуту) через: 1) «якісне» економічне зростання - без збільшення забруднення довкілля (напр., об’ємів викидів парникових газів [22, с. 10]), і 2) повернення виробництв з-за кордону (згадані вище «Форд» та «Крайлсер») та 3) безперешкодне нарощування глобального експорту енергоносіїв (в т. ч. нафти - вперше за 40 р.) [6, с. 38], продукції ВПК [23, с. 57], ГМО-продуктів та високотехнологічної продукції «ринків майбутнього»[5, с. 82; 23, с. 57].

За таких умов офіційний Вашингтон 1) мінімізував використання власної «жорсткої» сили на міжнародній арені інерційними заходами на Бл. і Сер. Сході (боротьба проти «Аль-Каїди» і згодом ДАЕШ) свідченням чого, зокрема, було і збереження в демократичній адміністрації республіканського, міністра оборони Р. Гейтса, а також 2) зменшив об'єми інвестицій та допомоги за кордоном, зосередившись, переважно, на використанні інших інструментів «м’якої» та «розумної» сили у планетарній політиці, 
особливо - дипломатії та власної структурної сили гегемона міжнародної системи. Уникаючи односторонніх дій (і втрат) в міжнародних відносинах, Б. Обама передав вирішення глобальних проблем багатостороннім механізмам - чи то в рамках спроби американо-китайського партнерства на початку свого правління [10], чи згодом - в рамках OOH, HATO, G7 i G20. Так, спираючись на свою вагу в міжнародній системі і глобальній економіці США: 1) ігнорували антикризові заходи, які намагались реалізувати ЄС і розташовані на його території фінансові центри, які керували міжнародними грошовими потоками [14, с. 12]; 2) встановили обмеження, через санкції, на експорт сировини та продукції ВПК з «держав-ізгоїв», особливо з РФ [23, с. 57]; 3) «стримували» економічно КНР як глобального конкурента [12, с. 80], паралельно повертаючи з нього виробництва [5, с. 84]; 4) приховано субсидували власних товаровиробників в обхід СОТ [14, с. 12] і 5) диктували власні правила в боротьбі за «ринки майбутнього» та робочі місця [5, с. 82]; 6) просували на глобальному ринку ГМО-продукцію [14, с. 12]. Дипломатія використовувалась адміністрацією Б. Обами, щоб недопустити висунення десятьма найбільшими кредиторами США, які надавали кошти на потреби американських фінансових установ [12, с. 69], політичних і економічних вимог до федерального уряду; для підготовки угод про вільну торгівлю; просування якісних, наукоємних товарів і послуг на критичних для Америки ринках АТР, КНР, СС [6, с. 40], спільного зі союзниками обмеження експорту з «держав-ізгоїв».

Результатом восьми років діяльності адміністрації Б. Обами стала реалізація схваленого економічними експертами, в т. ч. Нобелівськими лауреатами (К. Ерроу, Л. Клейном, Е. Мескіном, Д. МакФадденом, П. Семюельсоном і Р. Солоу), узгодженого обома партіями, Конгресом, Білим домом і ФРС, «класичного» $\mathrm{i}$ «єдино-правильного» плану виведення економіки країни з кризи, найглибшої після II світової війни. Наслідком його втілення стало збалансування федеральних витрат і за каденції Б. Обами, і на декаду вперед, оздоровлення фінансової сфери країни загалом [6, с. 34, 35, 37], скорочення дефіциту бюджету США, симулювання національних виробництва, зайнятості та розвитку інфраструктури [8, с. 34-35] на новій якісній основі («зеленій», високотехнологічній), зміна енергетичного дефіциту профіцитом, підвищення рівня життя «пересічних» американців і покращення його якості, зниження темпів економічної поляризації суспільства тощо. Завдяки цьому почалося відновлення «критичних» об'єктивних складових сили США - економічних (промислова потужність і ресурсний потенціал) i демографічних (освіта, здоров'я, професіоналізм американців), акумуляція «оптимальної» сили Америки, необхідні для успішного досягнення іiі цілей на глобальній арені, підвищення міри їх суб'єктності. Цими напрацюваннями і скористався чинний президент США - Д. Трамп, реалізуючи свою зовнішньополітичну програму.

Таким чином, економічний аспект діяльності адміністрації Б. Обами був одним із ключових упродовж восьми років його каденції. Йдеться про те, що саме господарські проблеми США та шкідливий вплив на них процесів у глобальній економіці підривали суб'єктність офіційного Вашингтона у політиці планети, його об’єктивні (матеріальні ресурси і засоби) і суб'єктивні (психологія, політична воля) складові «розумної» сили, зменшуючи можливості їх впливу на міжнародні процеси. Як наслідок, до вирішення економічних проблем Америки і їх негативного впливу на їі політичну систему, США зменшили активність у глобальній політиці. Свідченням цього було виведення у 2011 р. американських військ з Іраку та відмова Вашингтона від тривалих масштабних військових операцій загалом, проведення слабкої зовнішньої політики, близької до ізоляціонізму

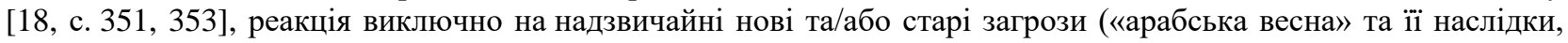
особливо, поява ДАЕШ, вторгнення РФ в Україну тощо) до моменту очікуваного відновлення економічного потенціалу Сполучених Штатів - навіть не за каденції Б. Обами, а за його наступників - згідно із очікуваннями економістів.

Висновки. Акцент на вирішенні внутрішніх проблем федерації - економічних і спричинених ними соціальних не означав повної відмови Вашингтона від участі у глобальній політиці. Швидше, мова йшла про його зсув від застосування засобів «жорсткої» сили, можливості використання яких визначаються наявними економічними ресурсами, до менш витратних засобів - «м'якої» сили. Також акцент президентської адміністрації на внутрішній політиці і відновленні господарства Америки парадоксально активізував участь Вашингтона у такій сфері глобальної політики як формування і підтримка міжнародних економічних режимів. 3 цією метою керівництво США використало наявні у нього засоби і продемонструвало свою гегемонію, вдавшись до односторонніх заходів у економіці Землі у 2008 р., а згодом - у боротьбі за ринки для американських підприємств через усунення для них торгівельних бар'єрів, проекти створення ЗВТ (трансатлантичної, транс-тихоокеанської) або, навпаки, створення торгівельних бар'єрів для іноземних підприємств через санкції для «держав-ізгоїв» (РФ, Сирії, КНДР), посилення позицій підприємств США на глобальному ринку шляхом створення їм переваг в рамках їх захисту від фінансової кризи. У свою чергу така комбінація дій США за кордоном не дозволяє говорити виключно про пасивний курс глобальної політики Б. Обами, а швидше про поєднання в його глобальній діяльності рис агресивної (запровадження санкційних режимів проти певних держав), активної (створення зон вільної торгівлі), консервативної (збереження впливу на Бл. Сході) і пасивної (реакція на появу ІДІЛ і дії Росії в Україні) політики, вибір кожної з яких зумовлювався як значенням певного зовнішнього виклику для США, так $\mathrm{i}$ наявністю в них ресурсів для відгуку на нього і внутрішньополітичного консенсусу щодо необхідності відповіді на нього. 
Втім, обрання Д. Трампа голосами численних представників американських низів і збіднілого середнього класу засвідчило недостатність, якщо не невдачу заходів Б. Обами у внутрішній політиці і, те, що реалізація його соціального плану не задовольнила їх ні фізично, ні морально. Демократи не знизили рівень незадоволення низів «непристойними бонусами» i приватними літаками керівників корпорацій американського сегмента глобальної «еліти Давосу» (в термінології С. Гантінгтона), в інтересах якої реалізувалась глобальна політика США до Д. Трампа і просувалась неоліберальна економічна глобалізація. Більше того, білі бідні маси після напівзаходів Б. Обами перейшли із демократичного табору в республіканський і підтримали обрання лідера з протилежними (антиглобалістськими та ізоляціоністськими установками). Щобільше, відмова США від гегемонії та експансіонізму у глобальній політиці за Д. Трампа на користь подальшої активізації внутрішньої політики і національних економічних та соціальних заходів (як реалізація гасла «America's first») чітко засвідчили, що попередній восьмирічний глобальний відступ Б. Обами на користь вирішення проблем американської глибинки був недостатнім. Свідченням цієї невдачі $є$ те, що США і далі втрачали по 0,5 млн. робочих місць щороку на користь Азї [18, с. 352]. Саме тому Д. Трамп, в інтересах американських низів і середнього класу, пішов далі Б. Обами і перейшов від відкриття глобальних ринків для США до масштабного глобального протекціонізму, здатного, на думку нового президента, полегшити становище частини американців - працюючих і пошукачів роботи, до наступного етапу - зламу глобальних економічних інститутів та руйнування міжнародних ринків, особливо трансатлантичного i тихоокеанського («Кімерики»), з метою обмеження доступу фірм з інших країн на ринок США. Це повинно полегшити діяльність на національному ринку місцевих виробників і їх працівників. Це, на нашу думку, засвідчує провал глобальних економічних ініціатив Б. Обами і є провісником змін економічної основи («базису» в марксистській термінології) глобальної політики і їі структури, які почались задовго до Д. Трампа і Б. Обами, але будуть тривати і після них, зумовивши формування нової структури глобальної політики i зміну місця у ній США.

\section{Бібліографічний список:}

1. Барак Обама в американской и российской политической графике / Е. С. Надточева, А. П. Чудинов, Е. В. Шустрова Вестник ЮУрГУ. Лингвистика. Челябинск, 2017. Т. 14. №2. С. 12-25.

2. Взаємозв'язок економіки і політики: особливості аргументації у промовах політиків / Штерма Т. В., Штерма I. М., Непийвода М. А. Збірник наукових працьь Таврійського державного агротехнологічного університету. Економічні науки. Мелітополь, 2013. № 2 (4). С. 342-351.

3. Городня Н. Д. Азійсько-тихоокеанська політика адміністрації Б. Обами Вісник Луганського НУ ім. Т. Шевченка. Луганськ, 2012. № 6 (2). С. 17-24.

4. Давыборец Е. Н. Формирование имиджей кандидатов в президенты США Дж. Маккейна и Б. Обамы Научные Ведомости БелГУ. История. Политология. Белгород, 2009. № 7 (62). С. 246-250.

5. Доминантные сферы-источники метафорической экспансии в речах Б. Обамы (идеологический аспект) / В. А. Каменева, А. А. Перевалова Вестник Челябинского ГУ. Филология. Искусствоведение. Челябинск, 2012. № 17 (271). Вып. 66. С. 80-86.

6. Евстафьев Д. С. Главные экономические итоги деятельности администрации президента Барака Обамы Общество. Среда. Развитие. Санкт-Петербург, 2016. № 2. С. 34-42.

7. Зубченко Л. А. Реформа финансового регулирования Б. Обамы (Сводный реферат) Социальные и гуманитарные науки. Отечественная и зарубежная литература. Сер. 2: Экономика. Реферативный журнал. Москва, 2010. № 4. С. 58-62.

8. Кириченко Э. План Обамы: оценка перспектив Прямые инвестиции. Москва, 2009. № 4 (84). С. 34-36.

9. Климанська Л. Зовнішня політика держави і міжнародні відносини / Політологія: Навч. посіб. / за наук. ред. А. Колодій. Львів, 2003. С. 527-550.

10. Косов А. П. Политика США в отношении Китая в период первого президентства Б. Обамы: сотрудничество или соперничество Міжнародні відносини. Політичні науки. Київ, $2015 . \quad № 5$. URL: http://journals.iir.kiev.ua/index.php/pol_n/article/view/2497/2228 (дата звернення: 02.08.2020)

11. Костюнина М. В. Сравнительный анализ риторической аргументации в предвыборном дискурсе Б. Обамы и Дж. Маккейна Политическая лингвистика. Екатеринбург, 2011. № 2 (36). С. 125-132.

12. Махмудов Р. Афганский кризис на фоне «проблемы 2011 года»: перспективы развития ситуации Центральная Азия и Кавказ. Лулео, 2010. Т. 13. Вып. 2. С. 67-81.

13. Новицький В. Глобальна фінансово-економічна криза: сутність, системність проявів та перспективи подолання Економічний часопис-XXI. Київ, 2009. № 1-2. С. 3-4.

14. Погорська I. I. Свропа у сучасній зовнішній політиці США: трансатлантизм і прагматика конкурентного партнерства Актуальні проблеми міжнародних відносин. Київ, 2011. Вип. 103. Ч. І. С. 9-16.

15. Розенау Дж. Управление неуправляемым: проблема глобального рассредоточения власти PsiFactory. URL: https://psifactory.livejournal.com/13648.html (дата звернення: 02.08.2020)

16. Садуов Р. Т. «Обращение к имени» как центральная агитационная составляющая предвыборной кампании Барака Х. Обамы Вестник Башкирского ун-та. Уфа, 2009. Т. 14. № 4. С. 1439-1443.

17. Садуов Р. Т. Автобиография как стержневая компонента политического дискурса Барака Обамы Политическая лингвистика. Екатеринбург, 2010. № 3 (33). С. 109-118. 
18. Смола Л. Обама, Барак Хусейн Американський президенціалізм: інститут глави держави в США y персоналіях від зародження до сьогодення / ред. Н. Хома. Львів, 2018. С. 347-356.

19. Татаринова О. В. Барак Обама - человек, которого «сделали» Ретроспектива. Калининград, 2015. Вып. 9. С. 125-133.

20. Трамп у «Твіттері» розкритикував Обаму, зокрема, через Крим Радіо Свобода: Міжнародні Новини. 2017. 07.03. URL: https://www.radiosvoboda.org/a/news/28355757.html (дата звернення: 30.07.2020).

21. Уманская А. Е. Стратегия удержания власти как одна из основных используемых стратегий президента США Барака Обамы в политическом интервью Вестник Челябинского ГУ. Филология. Искусствоведение. Челябинск, 2013. № 20 (311). Вып. 79. С. 105-107.

22. Фесенко М. В. Зовнішня та безпекова політика США і Франції: трансатлантичний вимір Міжнародні відносини. Політичні науки. Київ, 2015. № 9. С. 1-15.

23. Фролова О. А. Анализ внешнеполитических документов администраций Дж. Буша-Младшего и Б. Обамы как основополагающих стратегических доктрин политики США на международной арене Вестник РУДН. Политология. 2015. № 4. С. 53-58.

24. Haass R. Preface Foreign Policy Begins at Home: The Case for Putting America's House in Order. New York, NY, Basic Books, 2013. URL: https://www.basicbooks.com/titles/richard-n-haass/foreign-policy-beginsat-home/9780465071999/\#module-whats-inside (дата звернення: 10.07.2020).

25. Has U.S. Foreign Policy Changed Dramatically?: Foreign Affairs Asks the Experts Foreign Affairs. 2018. February 13. URL: https://www.foreignaffairs.com/ask-the-experts/2018-02-13/has-us-foreign-policy-changeddramatically (дата звернення: 01.08.2020).

26. National Security Strategy Washington, February 2015. 29 p. URL: https://obamawhitehouse.archives.gov/ sites/default/files/docs/2015_national_security_strategy_2.pdf (дата звернення 30.07.2020).

27. Tapper J. Interview With Former New York Mayor Rudy Giuliani. Aired 9-10a ET Aired November 13, 2016 09:00 ET CNN International Edition+: Transcripts. URL: http://transcripts.cnn.com/TRANSCRIPTS/1611/ 13/sotu.01.html (дата звернення: 30.07.2020).

\section{References:}

1. Barak Obama v amerikanskoy i rossiyskoy politicheskoy grafike (Barack Obama's Image In American And Russian Political Cartoon) / E. S. Nadtocheva, A. P. Chudinov, E. V. Shustrova Vestnik YuUrGU. Lingvistika (Bulletin of the South Ural State University. Linguistics). Chelyabinsk, 2017. T. 14. \#2. S. 12-25.

2. Vzaemozv'yazok ekonomiki i politiki: osoblivosti argumentatsiyi u promovah politikiv (The relationship between economics and politics: features of argumentation in the speeches of politicians) / Shterma T. V., Shterma I. M., Nepiyvoda M. A. Zbirnik naukovih prats Tavriyskogo derzhavnogo agrotehnologichnogo universitetu. Ekonomichni nauki (Collection of scientific works of the Tavria State Agrotechnological University (economic science). Melitopol, 2013. \#2 (4). S. 342-351.

3. Gorodnya N. D. Aziysko-tihookeanska politika administratsiyi B. Obami (Barack Obama Administration Asia Pacific Policy) Visnik Luganskogo NU Im. T. Shevchenka (Bulletin of Luhansk Taras Shevchenko National University). Lugansk, 2012. \#6 (2). S. 17-24. URL: http://elibrary.ivinas.gov.ua/653/1/V \#6_ Ch.1.pdf (Access date: 06.06.2020)

4. Davyborets E. N. Formirovanie imidzhey kandidatov v prezidentyi SShA Dzh. Makkeyna i B. Obamyi (Image Formation of The Presidential Candidates John Mccain And Barack Obama) Nauchnyie Vedomosti BelGU. Istoriya. Politologiya (Scientific bulletins of the Belgorod State University. History. Political science). Belgorod, 2009. \#7 (62). S. 246-250.

5. Dominantnyie sferyi-istochniki metaforicheskoy ekspansii v rechah B. Obamyi (ideologicheskiy aspekt) (Dominant Sphere-Sources of Metaphorical Expansion in B. Obama's Speeches (Ideological Aspect) / V. A. Kameneva, A. A. Perevalova Vestnik Chelyabinskogo GU. Filologiya. Iskusstvovedenie (Bulletin of Chelyabinsk State University. Philology. Art criticism). Chelyabinsk, 2012. \#17 (271). Vyip. 66. S. 80-86.

6. Evstafiev D. S. Glavnyie ekonomicheskie itogi deyatelnosti administratsii prezidenta Baraka Obamy (The major economic achievements of the President Barack Obama administration) Obschestvo. Sreda. Razvitie (Society. Environment. Development). Sankt-Peterburg, 2016. \#2. S. 34-42.

7. Zubchenko L. A. Reforma finansovogo regulirovaniya B. Obamyi (Svodnyiy referat) (B. Obama's financial regulation reform (Consolidated abstract) Sotsialnyie $i$ gumanitarnyie nauki. Otechestvennaya $i$ zarubezhnaya literatura. Ekonomika. Referativnyiy zhurnal (Social Sciences \& Humanities. Domestic \& Foreign Literature. Economics: Abstract Journal). Moskva, 2010. \#4. S. 58-62.

8. Kirichenko E. Plan Obamyi: otsenka perspektiv (Obama's plan: assessing the prospects) Pryamyie investitsii (Direct investments). Moskva, 2009. \#4 (84). S. 34-36.

9. Klimanska L. Zovnishnya politika derzhavi i mizhnarodni vidnosini (State foreign policy and international relations) / Politologiya: Navch. posib. (Political Science: Textbook) / za nauk. red. A. Kolodiy. Lviv, 2003. S. 527-550.

10. Kosov A. P. Politika SShA v otnoshenii Kitaya v period pervogo prezidentstva B. Obamyi: sotrudnichestvo ili sopernichestvo (US policy toward China during Obama's first presidency: cooperation or rivalry) Mizhnarodni vidnosini. Politichni nauki (International relations, part “Political sciences”). Kyiv, $2015 . \quad$ \#5. URL: http://journals.iir.kiev.ua/index.php/pol_n/article/view/2497/2228 (Access date: 02.08.2020) 
11. Kostyunina M. V. Sravnitelnyiy analiz ritoricheskoy argumentatsii v predvyibornom diskurse B. Obamyi i Dzh. Makkeyna (Comparative Analysis of Rhetoric Argumentation in Election Discourse of B. Obama and J. Mccain) Politicheskaya lingvistika (Political Linguistics). Ekaterinburg, 2011. \#2 (36). S. 125-132.

12. Makhmudov R. Afganskiy krizis na fone «problemyi 2011 goda»: perspektivyi razvitiya situatsii (The Afghan Crisis and the 2011 Problem: What's Next?) Tsentralnaya Aziya $i$ Kavkaz (Central Asia and the Caucasus). Luleo, 2010. T. 13. Vyip. 2. S. 67-81.

13. Novitskiy V. Globalna finansovo-ekonomichna kriza: sutnist, sistemnist proyaviv ta perspektivi podolannya (The global financial and economic crisis: the essence, systemic manifestations and prospects for overcoming) Ekonomichniy chasopis-XXI (The Economic Annals-XXI). Kyiv, 2009. \#1-2. S. 3-4.

14. Pogorska I. I. Evropa u suchasniy zovnishniy polititsi SShA: transatlantizm i pragmatika konkurentnogo partnerstva (Europe in modern US foreign policy: transatlanticism and the pragmatics of competitive partnership) Aktualni problemi mizhnarodnih vidnosin (Actual problems of international relations). Kyiv, 2011. Vip. 103. Ch. I. S. 9-16.

15. Rozenau Dzh. Upravlenie neupravlyaemyim: problema globalnogo rassredotocheniya vlasti (Governing the ungovernable: The challenge of a global disaggregation of authority) PsiFactory. URL: https://psifactory.livejournal.com/13648.html (Access date: 02.08.2020)

16. Saduov R. T. «Obraschenie k imeni» kak tsentralnaya agitatsionnaya sostavlyayuschaya predvyibornoy kampanii Baraka H. Obamyi («Appeal to the name» as the central campaign component of the election campaign of Barack H. Obama) Vestnik Bashkirskogo un-ta (Bulletin of Bashkir University). Ufa, 2009. T. 14. \#4. S. $1439-1443$.

17. Saduov R. T. Avtobiografiya kak sterzhnevaya komponenta politicheskogo diskursa Baraka Obamyi (Autobiography as a core component of Barack Obama's political discourse) Politicheskaya lingvistika (Political Linguistics). Ekaterinburg, 2010. \#3 (33). S. 109-118.

18. Smola L. Obama, Barak Huseyn Amerikanskiy prezidentsializm: Institut glavi derzhavi $v$ SShA $u$ personaliyah vid zarodzhennya do sogodennya (American presidentialism: the institution of the head of state in the United States in personalities from its inception to the present) / red. N. Khoma. Lviv, 2018. S. 347-356.

19. Tatarinova O. V. Barak Obama - chelovek, kotorogo «sdelali» (Barak Obama - a man-made man) Retrospektiva (Retrospective). Kaliningrad, 2015. Vyip. 9. S. 125-133.

20. Tramp u «Tvitteri» rozkritikuvav Obamu, zokrema, cherez Krim (Trump criticized Obama on Twitter, particularly through Crimea) Radio Svoboda: Mizhnarodni Novini (Radio Liberty International News). 2017. 07.03. URL: https://www.radiosvoboda.org/a/news/28355757.html (Access date: 30.07.2020)

21. Umanskaya A. E. Strategiya uderzhaniya vlasti kak odna iz osnovnyih ispolzuemyih strategiy prezidenta SShA Baraka Obamyi v politicheskom intervyu (Strategy of Retention of Power as One of the Main Strategies Used in Political Interview of the US President Barack Obama) Vestnik Chelyabinskogo GU. Filologiya. Iskusstvovedenie (Bulletin of Chelyabinsk State University. Philology. Art criticism). Chelyabinsk, 2013. \#20 (311). Vyip. 79. S. 105-107.

22. Fesenko M. V. Zovnishnya ta bezpekova politika SShA i Frantsiyi: transatlantichniy vimir (US and French foreign and security policies: the transatlantic dimension) Mizhnarodni vidnosini. Politichni nauki (International relations, part "Political sciences"). Kyiv, 2015. \#9. S. 1-15.

23. Frolova O. A. Analiz vneshnepoliticheskih dokumentov administratsiy Dzh. Busha-Mladshego i B. Obamyi kak osnovopolagayuschih strategicheskih doktrin politiki SShA na mezhdunarodnoy arene (The Analysis of George W. Bush and Barack Obama Administrations' Foreign Policy Documents as a Fundamental Strategic Doctrines of the U. S. Policy in the International Arena) Vestnik RUDN. Politologiya (Bulletin of People's Friendship University of Russia. Political Science). 2015. \#4. S. 53-58.

24. Haass R. Preface Foreign Policy Begins at Home: The Case for Putting America's House in Order. New York, NY, Basic Books, 2013. URL: https://www.basicbooks.com/titles/richard-n-haass/foreign-policy-beginsat-home/9780465071999/\#module-whats-inside (Access date: 10.07.2020)

25. Has U.S. Foreign Policy Changed Dramatically?: Foreign Affairs Asks the Experts Foreign Affairs. 2018. February 13. URL: https://www.foreignaffairs.com/ask-the-experts/2018-02-13/has-us-foreign-policy-changeddramatically (Access date: 01.08.2020)

26. National Security Strategy Washington, February 2015. 29 p. URL: https://obamawhitehouse.archives.gov/ sites/default/files/docs/2015_national_security_strategy_2.pdf (Access date: 30.07.2020)

27. Tapper J. Interview With Former New York Mayor Rudy Giuliani. Aired 9-10a ET Aired November 13, 2016 09:00 ET CNN International Edition+: Transcripts. URL: http://transcripts.cnn.com/TRANSCRIPTS/1611/ 13/sotu.01.html (Access date: 30.07.2020) 